\title{
INDICATOR-BASED ANALYSIS OF SOCIALLY SENSITIVE AND TERRITORIALLY SUSTAINABLE DEVELOPMENT IN RELATION TO HOUSEHOLD ENERGY CONSUMPTION
}

\author{
Jan Kazak $^{1}$, Halina Dziezyc ${ }^{1}$, Iwona Forys ${ }^{2}$, Szymon Szewranski ${ }^{1}$ \\ ${ }^{1}$ Wroclaw University of Environmental and Life Sciences, Poland; ${ }^{2}$ University of Szczecin, Poland \\ szymon.szewranski@upwr.edu.pl
}

\begin{abstract}
One of the major fields of actions in sustainable development is energy. The correlation between the number of renewable energy sources and selected socioeconomic variables was already analysed, however, other energy indicators used for sustainable development assessment should be also checked. This issue is especially important outside the biggest cities in Poland due to the different energy use in relation to the density of urban development. The aim of the study is to identify the correlation between the energy use and other factors used to assess the sustainable development on the case of units of rural and semi-rural character. The studies used data from the public statistics system, the objects were NUTS-4 districts, according to the Eurostat classification. Classical statistical methods were used in the causality study: independence tests and correlation and association measures of random variables (Spearman's rank correlation), and materiality tests of particular variables and their groups in linear econometric models. There was a statistically significant cause and effect relationship between electricity consumption and the amount of mixed municipal waste collected from households during the year, the number of household sewage treatment plants, natural growth per 1000 population, demographic dependency ratio, average usable area of a flat, the number of unemployed registered with higher education in relation to the number of people of working age and the share of the long-term unemployed registered at the age of 55-64 in the total number of unemployed at that age. In addition, a strong non-linear correlation relationship with the usable area of a flat per person was obtained. Subsequent research will concern searching for indicated dependencies in groups of similar objects.
\end{abstract}

Keywords: energy consumption, sustainable development indicators, regional development.

\section{Introduction}

On the $25^{\text {th }}$ of September 2015 over 150 countries agreed on new 17 ambitious Sustainable Development Goals, also known as the Global Goals [1]. The 2030 Agenda for Sustainable Development replaces Agenda 21 and the Millennium Development Goals which were declared in September 2000 [2]. Both, Millennium Development Goals and Sustainable Development Goals were concerned on similar issues, and include the set of goals like: end inequality, hunger and poverty, take action on climate change and the environment degradation, ensure access to affordable and clean energy, promote health and improve education, build strong institutions and partnerships, etc. As we can see, countries should not focus only on one selected issue, but should take holistic actions in order to improve the quality of life [3;4]. The question is, if countries effectively influence on different aspects in regional development management in order to reach sustainable development goals.

One of the major fields of actions in sustainable development is energy. In case of the European Union, the implementation of sustainable development goals in that field is represented in 2020 climate and energy package [5] and financially supported by the EU funds [6]. The package sets three key targets: $20 \%$ cut in greenhouse gas emissions (from 1990 levels), $20 \%$ of EU energy from renewables, and $20 \%$ improvement in energy efficiency. Actions in energy performance improvement are especially crucial in Member States, which are located in the Central Europe due to high level of air pollution [7]. One of the reasons of such situation is relatively late change in mechanisms of regional development systems, which appeared in 1990s, and influenced new patterns of urban development [8; 9]. The biggest country in that region is Poland, which was selected as a case for further analysis. To manage regional development successfully regional authorities need to know the relations between those aspects and other drivers defining the development level. The correlation between the number of renewable energy sources and selected socioeconomic variables was already analysed [10], however, other energy indicators used for sustainable development assessment should be also checked. This issue is especially important outside the biggest cities due to the different energy use in relation to the density of urban development [11-14].

In 2017 the Polish Government adopted Strategy for Responsible Development [15]. The agenda specifies major projects and the main goals to be achieved in the perspective by 2020 and 2030. Newly declared policy is founded on principles of sustainable development based on solidarity. Facilitating 
sustainable development will provide for promoting smaller centres. One of three objectives is socially sensitive and territorially sustainable development, which includes quality of life improvement, social cohesion promotion and self-sustaining local development. Justification of the used variables is based literally on the Strategy, which refers to: environment and natural resources management (set of variables 1), active family policy (2.1), reducing poverty and social exclusion (2.2), improve the society's level of education (2.3), increasing and facilitating the use of human capital on the labour market (2.4), fulfilment of basic livelihood needs (2.5), improvement of quality and independence in everyday life, including the prolonged professional activity (2.6).

Among others areas, which have an impact on the achievement of the objective adopted in the Strategy [15], is energy. As Poland should remain sovereign in the field of energy supply, it requires diversification of sources, directions and suppliers. The Strategy incorporates both centralized and diffused strategic projects. According to diversified energetics, the project intended to develop production of electricity with the use of renewable energy sources for the needs of a local community, and establishment of regulatory conditions allowing for development of local energetically balanced areas, like clusters of energy, energy cooperatives, etc.

Identification of drivers related with the improvement of energy performance of houses [15] can be useful for decision makers for better energy investment planning [17; 18] and land use modelling for better understanding the urbanisation process [19]. Therefore, the aim of the study is to identify the correlation between the energy use and other factors used to assess the sustainable development on the case of units with rural and semi-rural character. The lowest level of central government administration in Poland is set at "powiat", which covers the same units as NUTS-4. The "Strategy for Responsible Development" will be implemented according to the subsidiarity principle and has to be monitored and evaluated at the most basic level in order to support effective management by detailed measures.

\section{Materials and methods}

Data from the Central Statistical Office (GUS) and the Statistical Office (US) in Katowice concerning the values of Poland's sustainable development indicators [20, 21] were used in the study. Indicator values are available for NUTS-4 units, according to the Eurostat classification [22] for 2015. Urban districts that cover the largest cities in Poland are excluded from the survey.

Variables were analysed in seven subgroups of two important indicators affecting household electricity consumption: environmental order (three variables in one subgroup) and social order (six subgroups, thirteen variables). The choice of the variables was mainly determined by substantive reasons $[10 ; 14]$, as well as by the access to data in the same research period and for the same objects (Table 1).

The econometric model for development patterns assessment was used [23]. In the first step, the basic descriptive characteristics of the selected variables and the interdependence of the variables in groups were examined. Highly correlated variables within the group indicate a high degree of interdependence and duplication of information in econometric models, when they are included as explanatory variables. On the other hand, explanatory variables should be highly correlated with the explanatory variable.

Classical statistical methods in the causality study can be divided into two groups: independence tests and correlation and association measures of random variables, while the second group consists of materiality tests for particular variables and their groups in econometric models. The first group uses the $\chi^{2}$ independence test and the associated force measures in the form of Czuprow's, Cramer's coefficients or Pearson's contingency coefficient. They indicate the existence of dependency, but do not provide information on the direction of the examined dependency. A better tool for causation analysis of economic variables is an econometric model, e.g. single-equation linear model. Practical verification of the hypothesis of no causality in the sense of Granger may take place:

- as a causality examination of individual explanatory variables individually, then the null hypothesis $H_{0}: \alpha=0$, and the Student's $t$-test is used for the assessment, 
- joint testing of causality of the whole vector of explanatory variables, then the null hypothesis $H_{0}: \alpha_{1}=\alpha_{2}=\ldots=\alpha_{k}=0$, against the alternative hypothesis $H_{1}$, that at least one parameter $\alpha_{i} \neq 0$, the statistics is based on the breakdown $F$ with $(k, n-k-1)$ degrees of freedom.

Table 1

\section{Variables adopted for survey}

\begin{tabular}{|c|c|}
\hline Symbol & Variable \\
\hline$X 0$ & Electricity consumption of households (kWh per person) \\
\hline \multicolumn{2}{|c|}{ 1. Indicators of environmental order } \\
\hline$X 1$ & Amount of mixed municipal waste from households collected per year (kg per inhabitant) \\
\hline$X 2$ & Number of household sewage treatment plants in district \\
\hline$X 3$ & Number of wild landfill sites per $100 \mathrm{~km} 2$ \\
\hline \multicolumn{2}{|c|}{ 2. Social order indicators } \\
\hline \multicolumn{2}{|c|}{ 2.1 Demographic changes } \\
\hline$X 11$ & Natural growth rate per 1000 population \\
\hline$X 12$ & $\begin{array}{l}\text { Balance of migration for permanent residence of people of working age per } 10 \text { thousand } \\
\text { working age population }\end{array}$ \\
\hline$X 13$ & $\begin{array}{l}\text { Demographic dependency ratio - number of people of post-working age per } 100 \text { people of } \\
\text { working age }\end{array}$ \\
\hline$X 14$ & $\begin{array}{l}\text { Demographic dependency ratio - number of people of non-productive age per } 100 \text { people } \\
\text { of working age }\end{array}$ \\
\hline \multicolumn{2}{|c|}{ 2.2 Poverty and living conditions } \\
\hline$X 21$ & $\begin{array}{l}\text { Share of persons in households benefiting from community social assistance in total } \\
\text { population }\end{array}$ \\
\hline$X 22$ & Average gross monthly salary (PLN) \\
\hline$X 23$ & Average usable area of a flat $\left(\mathrm{m}^{2}\right.$ per person) \\
\hline \multicolumn{2}{|c|}{ 2.3 Education } \\
\hline$X 31$ & Share of children under pre-school education in the total number of children aged 3-5 (\%) \\
\hline$X 32$ & Pass rate of secondary school final examinations in general secondary schools \\
\hline \multicolumn{2}{|c|}{ 2.4 Access to labour market } \\
\hline$X 41$ & $\begin{array}{l}\text { Percentage of long-term unemployed (longer than } 1 \text { year) in the total number of registered } \\
\text { unemployed }(\%)\end{array}$ \\
\hline$X 42$ & $\begin{array}{l}\text { Number of registered unemployed women in relation to the number of people of working } \\
\text { age }(\%)\end{array}$ \\
\hline$X 43$ & $\begin{array}{l}\text { Number of registered unemployed with higher education in relation to the number of } \\
\text { people of working age }(\%)\end{array}$ \\
\hline$X 44$ & Registered unemployment rate (\%) \\
\hline \multicolumn{2}{|c|}{ 2.5 Consumption patterns } \\
\hline$X 51$ & Number of passenger cars per 1000 population \\
\hline$X 52$ & Annual consumption of gas in households $\left(\mathrm{m}^{3}\right.$ per inhabitant) \\
\hline$X 53$ & Annual consumption of water in households ( $\mathrm{m}^{3}$ per inhabitant) \\
\hline \multicolumn{2}{|c|}{ 2.6 Adequacy of income in old age } \\
\hline$X 61$ & $\begin{array}{l}\text { Percentage of registered long-term unemployed (longer than } 1 \text { year) aged 55-64 in the } \\
\text { total number of the unemployed aged 55-64 (\%) }\end{array}$ \\
\hline$X 62$ & $\begin{array}{l}\text { Percentage of people in the post-working age group in households benefiting from } \\
\text { community social assistance in the total number of people in this age group (\%) }\end{array}$ \\
\hline
\end{tabular}

Source: $[20 ; 21]$

Both approaches were used in the study and the calculations were performed in Dell Statistica (Data Analysis Software System Version 13) [24] and Statistica 10.

Additionally, frequently observed asymmetry of distributions and outliers indicate the necessity to determine correlations not only linear (Pearson's). It is also useful to determine monotonic relations between indicators, i.e. the use of Spearman's correlation coefficients [25]. In the case of significant 
correlations (at a level of $p \leq 0.05$ ), it can then be assessed whether it causes a conflict in terms of the desired direction of the indicator change.

\section{Results and discussion}

The study analysed the basic statistical correlations and examined the correlation between electricity consumption of households per capita $(X 0)$ and other sustainable development indicators from the groups: environmental order $(X 1-X 3)$ and social order $(X 21-X 62)$. In the first step, descriptive statistics of the set of variables adopted for the survey were designated in order to determine the structure of the examined objects. The obtained values are presented in Table 2.

Table 2

Basic descriptive statistics of the variables analysed

\begin{tabular}{|c|c|c|c|c|c|c|}
\hline Variable & Average & Median & $\begin{array}{c}\text { Standard } \\
\text { deviation }\end{array}$ & $\begin{array}{c}\text { Coefficient of } \\
\text { variation (\%) }\end{array}$ & Kurtosis & $\begin{array}{c}\text { Skewness } \\
\text { (Asymmetry) }\end{array}$ \\
\hline$X 0$ & 714.5 & 694.3 & 122.6 & 17.16 & 2.23 & 1.02 \\
\hline$X 1$ & 146.0 & 153.6 & 52.9 & 36.22 & -0.76 & -0.1 \\
\hline$X 2$ & 621.9 & 436.5 & 618.2 & 99.41 & 7.03 & 2.14 \\
\hline$X 3$ & 1.10 & 0.5 & 1.5 & 141.11 & 19.22 & 3.73 \\
\hline$X 11$ & -0.80 & -0.5 & 2.3 & -298.05 & 0.67 & -0.04 \\
\hline$X 12$ & -19.7 & -27.8 & 40.4 & -205.24 & 6.85 & 2.1 \\
\hline$X 13$ & 29.3 & 28.9 & 3.5 & 11.8 & 0.75 & 0.53 \\
\hline$X 14$ & 59.0 & 58.8 & 2.7 & 4.53 & 0.12 & 0.07 \\
\hline$X 21$ & 9.00 & 8.6 & 3.2 & 35.73 & 0.12 & 0.48 \\
\hline$X 22$ & 3,440 & $3,372.7$ & 409.4 & 11.9 & 21.6 & 3.42 \\
\hline$X 23$ & 26.8 & 26.4 & 2.9 & 10.86 & 2.45 & 1.09 \\
\hline$X 31$ & 77.7 & 77.3 & 8.3 & 10.64 & 0.04 & 0.03 \\
\hline$X 32$ & 84.5 & 86.1 & 8.5 & 10.08 & 6.5 & -1.97 \\
\hline$X 41$ & 38.0 & 38.1 & 7.3 & 19.09 & -0.02 & -0.22 \\
\hline$X 42$ & 15.0 & 14.6 & 4.8 & 32.01 & -0.56 & 0.26 \\
\hline$X 43$ & 0.80 & 0.7 & 0.3 & 39.51 & 0.17 & 0.75 \\
\hline$X 44$ & 13.0 & 12.3 & 5.2 & 40.13 & -0.1 & 0.54 \\
\hline$X 51$ & 550.6 & 549.3 & 69.1 & 12.56 & 7.59 & 1.16 \\
\hline$X 52$ & 74.0 & 66.2 & 61.6 & 83.23 & 10.91 & 2.55 \\
\hline$X 53$ & 30.4 & 30 & 7.4 & 24.34 & 2.28 & -0.04 \\
\hline$X 61$ & 50.3 & 50.6 & 9 & 17.94 & 0.47 & -0.42 \\
\hline$X 62$ & 3.50 & 3.4 & 1.1 & 30.9 & 0.78 & 0.58 \\
\hline
\end{tabular}

Source: own study

In most cases, the analysed set of objects is characterized by moderate or strong right-side asymmetry (variables $X 0, X 2, X 2, X 4, X 12, X 22, X 23, X 51, X 52$ ), which suggests using Spearman's correlation in further calculations. A moderate left-hand asymmetry occurred with the $X 32$ variable. In other cases, there is a slight right or left asymmetry. Differentiation of the examined objects is indicated by coefficients of variation, which characterise the ratio of severity of side causes to major causes. Among the analysed variables, except for one case (variable $X 14$ ), the coefficient of variation exceeds $10 \%$. This means that in the case of grouping of objects or multidimensional analysis, they bring significant information about the examined phenomenon and have discriminatory abilities [25].

Due to the nature of the data (no normal distributions of the majority of characteristics, outliers) and the willingness to take into account not only linear relationships, the next step determines the Spearman's correlation coefficients successively for each variable in both groups and the variable electricity consumption of households $(X 0)$.

The results of the Spearman's correlation coefficient analysis and identification of conflicts between the indicators are presented in Table 3.

Although the correlation itself is not a proof of the existence of cause and effect relationships, there has been a discussion on relations that may indicate the lack of such relationships. For indicators 
of sustainable development, the Central Statistical Office (GUS) has determined the desired directions of changes: increase or decrease in the indicator value. The proper socio-economic policy is determined by implementation of these guidelines. Based on the calculated Spearman's correlation indicator between the electricity consumption of households and other factors, it was determined whether there is a conflict between reducing average electricity consumption and improving other indicators. For five variables $(X 3, X 13, X 41, X 52, X 61)$ the determined correlation coefficients are statistically insignificant due to the adopted confidence level $(p \leq 0,05)$. Correlations are high in four cases of variables: Share of persons in households benefiting from community social assistance in total population (X21), Average usable area of a flat (X23), Number of registered unemployed women in relation to the number of people of working age (X42) and Annual consumption of water in households (X53). However, only for variable $X 23$ the correlation coefficient is greater than 0.5 (Fig. 1).

Table 3

Results of the correlation analysis

\begin{tabular}{|c|c|c|c|c|c|}
\hline Variable & $\begin{array}{l}\text { Average } \\
\text { indicator } \\
\text { value }\end{array}$ & $\begin{array}{c}\text { Desired } \\
\text { direction of } \\
\text { changes }\end{array}$ & $\begin{array}{l}\text { Spearman's } \\
\text { correlation } \\
\text { coefficient }\end{array}$ & Probability & $\begin{array}{l}\text { Conflict based } \\
\text { on correlation }\end{array}$ \\
\hline $\mathrm{X} 0$ & 714.5 & decrease & 1.000 & - & - \\
\hline $\mathrm{X} 1$ & 146.0 & decrease & 0.253 & 0.000 & no \\
\hline $\mathrm{X} 2$ & 621.9 & increase & 0.300 & 0.000 & yes \\
\hline X3 & 1.10 & decrease & 0.127 & 0.073 & - \\
\hline $\mathrm{X} 11$ & -0.80 & increase & 0.172 & 0.002 & yes \\
\hline $\mathrm{X} 12$ & -19.7 & increase & 0.389 & 0.000 & yes \\
\hline $\mathrm{X} 13$ & 29.3 & decrease & 0.036 & 0.528 & - \\
\hline $\mathrm{X} 14$ & 59.0 & decrease & 0.122 & 0.03 & no \\
\hline $\mathrm{X} 21$ & 9.00 & decrease & -0.450 & 0.000 & yes \\
\hline $\mathrm{X} 22$ & 3,440 & increase & 0.29 & 0.000 & yes \\
\hline $\mathrm{X} 23$ & 26.8 & increase & 0.604 & 0.000 & yes \\
\hline X31 & 77.7 & increase & 0.327 & 0.000 & yes \\
\hline X32 & 84.5 & increase & -0.173 & 0.002 & no \\
\hline X41 & 38.0 & decrease & -0.035 & 0.536 & - \\
\hline $\mathrm{X} 42$ & 15.0 & decrease & -0.474 & 0.000 & yes \\
\hline X43 & 0.80 & decrease & -0.362 & 0.000 & yes \\
\hline $\mathrm{X} 44$ & 13.0 & decrease & -0.385 & 0.000 & yes \\
\hline X51 & 550.6 & decrease & 0.342 & 0.000 & no \\
\hline X52 & 74.0 & decrease & 0.015 & 0.791 & - \\
\hline X53 & 30.4 & decrease & 0.424 & 0.000 & no \\
\hline X61 & 50.3 & decrease & 0.049 & 0.385 & - \\
\hline X62 & 3.50 & decrease & -0.291 & 0.000 & yes \\
\hline
\end{tabular}

Source: own study

In addition, the relationship between household electricity consumption and average usable area is positive, which means that as the usable area of a flat increases, the electricity consumption does so also. A similar positive relationship also exists with household water consumption. On the other hand, a negative relation takes place with the variable share of persons in households benefiting from community social assistance in total population and the variable number of registered unemployed women in relation to the number of people of working age. The obtained directions of electricity consumption of households relation with the analysed variables are consistent with the desired direction of GUS sustainable development indicators.

However, there are many situations, where a favourable change in one indicator is associated with an adverse change in another. Identifying this type of situation may serve to improve processes for implementing the idea of sustainable development. In order to search for the combined effect of the analysed variables (after elimination of variables highly correlated in particular groups and cases with 
lack of data) on household electricity consumption, parameters of a multiple regression model were estimated, using rolling regression [14, 26]. The results are presented in Table 4.
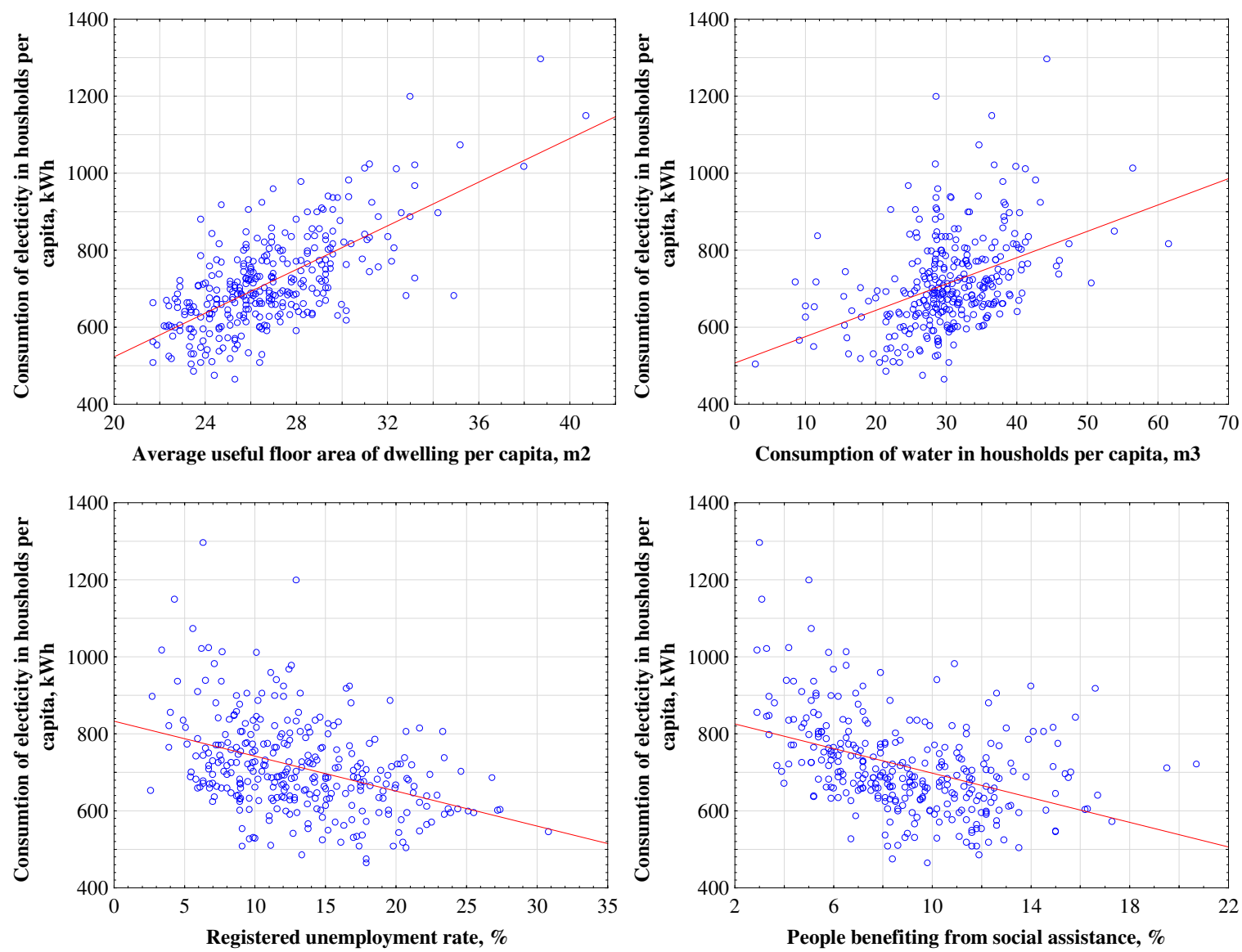

Fig. 1. Scatter plots for correlation between consumption of electricity in households per capita and chosen sustainable development indicators (source: own study)

Table 4

Summary of rolling regression of dependent variable $X 0$

\begin{tabular}{|c|c|c|c|c|c|c|}
\hline \multirow[t]{2}{*}{$N=186$} & \multicolumn{6}{|c|}{$\begin{array}{l}R=0.827, R^{2}=0.684 \\
F(10.175)=38.013 p<0.0000 \\
\text { Standard error of estimation: } 70.130\end{array}$} \\
\hline & $b^{*}$ & $S E$ & $b$ & $S E$ & $t(\mathbf{1 7 5})$ & $p$ \\
\hline Absolute term & - & - & -415.90 & 162.91 & -2.553 & 0.0115 \\
\hline$X 23$ & 0.58 & 0.06 & 24.43 & 2.36 & 10.365 & 0.0000 \\
\hline$X 43$ & -0.34 & 0.06 & -140.03 & 25.25 & -5.545 & 0.0000 \\
\hline$X 61$ & 0.13 & 0.06 & 1.78 & 0.78 & 2.282 & 0.0237 \\
\hline$X 1$ & 0.23 & 0.05 & 0.51 & 0.12 & 4.282 & 0.0000 \\
\hline$X 2$ & 0.14 & 0.05 & 0.03 & 0.01 & 3.0945 & 0.0023 \\
\hline$X 11$ & 0.15 & 0.05 & 8.12 & 2.58 & 3.150 & 0.0019 \\
\hline$X 14$ & 0.12 & 0.05 & 5.46 & 2.25 & 2.427 & 0.0162 \\
\hline$X 22$ & 0.09 & 0.05 & 0.02 & 0.01 & 1.881 & 0.0616 \\
\hline$X 44$ & 0.17 & 0.09 & 4.04 & 2.05 & 1.967 & 0.0508 \\
\hline$X 42$ & -0.13 & 0.09 & -3.26 & 2.20 & -1.480 & 0.1407 \\
\hline
\end{tabular}

\section{Source: own study}

The analysis of the estimated parameters of the regression model indicates a negative dependence of electricity consumption by households with the variable number of registered unemployed with higher education in relation to the number of people of working age (group labour market access). The $1 \%$ increase in unemployment results in a decrease in annual electricity consumption by 0.34 $\mathrm{kWh} /$ person, with other variables fixed (ceteris paribus). Other significant variables in the linear 
model $(X 1, X 2, X 11, X 14, X 23, X 43, X 61)$ deviate from the variables relevant in Spearman's correlation analysis. This is the result of a heterogeneous group of objects and non-linear relationships between the variables.

Summing up the study, clustering and concentration was carried out to analyse the development patterns [27]. The objects (districts) were grouped using a response variable and statistically significant explanatory variables from the presented model of multiple regression (Table 4), with Euclidean distance and a single linkage. The grouping divided the objects into four separate groups of districts, out of which three deviating from the others were indicated in Table 5.

Table 5

\section{Groups of districts deviating due to grouping variables statistically significant in the model $(X 0, X 1, X 2, X 11, X 14, X 23, X 43, X 61)$}

\begin{tabular}{|c|c|c|}
\hline Group 1 & Group 2 & Group 3 \\
\hline Piaseczno & Zgierz & Grójec \\
\hline Warszawa Zachód & Legionowo & Kraków \\
\hline Tatra & Grodzisk & Wielice \\
\hline- & Kolbuszowa & Łomża \\
\hline- & Suwałki & Zambrów \\
\hline- & Nowa Sól & Sejny \\
\hline- & Zielona Góra & Grudziądz \\
\hline- & Żagań & - \\
\hline
\end{tabular}

Source: own study

Group 1 included districts adjacent to the capital (Warsaw) and the Tatra district (the capital of winter sports). In group 2 there are districts of North-Eastern Poland with districts neighbouring Warsaw and two districts of Western Poland. Group 3 comprises districts adjacent to large urban agglomerations such as Warsaw, Krakow and Torun. The direction of further research should take into account the diversity of the surveyed objects due to the variables with significant impact on electricity consumption, which are indicators of sustainable development suggested in public statistics, also in urban areas. All indicators describing sustainable development should be analysed in a strong relation with the quality of life [3] and the living conditions [28].

\section{Conclusions}

1. The obtained directions of electricity consumption of households with social order indicators are consistent with the desired direction of GUS sustainable development indicators.

2. High correlation coefficients were recorded in four cases of variables: share of persons in households benefiting from community social assistance in total population, average usable area of a flat, number of registered unemployed women in relation to the number of people of working age and annual consumption of water in households.

3. All actions aiming quality of life improvement connected with raising the average usable area per person might cause the increase of electricity consumption in households. Therefore, there is a need to apply solutions, which would enable to find an acceptable trade-off between those two aspects, e.g. energy-saving technologies, thermal insulation of buildings.

4. The increase of electricity consumption is related with the increase of water consumption, therefore, the effective resources management should include integrated actions, which result in reshaping consumption patterns.

5. Further studies should take into account the similarity of the investigated objects.

\section{References}

[1] United Nations. Transforming our world: the 2030 Agenda for Sustainable Development. Resolution adopted by the General Assembly on 25 September 2015. A/RES/70/1. 2015.

[2] United Nations. United Nation Millennium Declaration, Resolution adopted by the General Assembly. A/RES/55/2. 2000.

[3] Przybyla K., Kulczyk-Dynowska A., Kachniarz M. Quality of Life in the Regional Capitals of Poland. Journal of Economic Issues, Vol. 48, Issue 1, 2014, pp. 181-196.

[4] Pasten C., Santamarina J.C. Energy and quality of life. Energy Policy, Vol. 49, 2012, pp. 468-476. 
[5] European Commission. Analysis of options beyond $20 \%$ GHG emission reductions: Member State results. Commission Staff Working Paper, SWD(2012) 5 final.

[6] Swiader M., Tokarczyk-Dorociak K. Szewranski S., Kazak J. Analiza zapisów regionalnych programów operacyjnych w latach 2014-2020 w kontekście finansowania inwestycji z zakresu OZE (Analysis of regional operational programmes for the 2014-2020 period in the context of financing the renewable energy investments). Rynek Energii, 2016, no. 3, (In Polish), pp. 72-80.

[7] Zyromski A., Biniak-Pierog M., Burszta-Adamiak E., Zamiar Z. Evaluation of relationship between air pollutant concentration and meteorological elements in winter months. Journal of Water and Land Development, no. 22, 2014, pp. 25-32.

[8] Warczewska B., Przybyla K. Implikacje wielofunkcyjnego rozwoju obszarów wiejskich w strefie podmiejskiej Wrocławia (The implications of the multifunctional rural development in Wroclaw suburban zone). Infrastructure and Ecology of Rural Areas, no. 2/III, 2012, (In Polish), pp. 89100.

[9] Solecka I., Sylla M., Swiader M. Urban Sprawl Impact on Farmland Conversion in Suburban Area of Wroclaw, Poland. IOP Conference Series: Materials Science and Engineering, vol. 245, "World Multidisciplinary Civil Engineering-Architecture-Urban Planning Symposium WMCAUS", June 12-16, 2017, Prague, Czech Republic, 072002.

[10] Hernik J., Rutkowska A., Noszczyk T. Correlation between selected socioeconomic variables and the number of renewable energy sources in Swietokrzyskie voivodeship (Poland). Proceedings of 15th International Scientific Conference "Engineering for rural development", May 25-27, 2016, Jelgava, Latvia, pp. 498-504.

[11] Skiba M., Mrowczynska M., Bazan-Krzywoszanska A. Modeling the economic dependence between town development policy and increasing energy effectiveness with neural networks. Case study: The town of Zielona Gora. Applied Energy, Vol. 188, 2017, pp. 356-366.

[12] Bazan-Krzywoszanska A., Mrowczynska M., Skiba M., Laczak A. Economic conditions for the development of energy efficient civil engineering using RES in the policy of cohesion of the European Union (2014-2020). Case study: The town of Zielona Gora. Energy and Buildings, Vol. 118, 2016, pp. 170-180.

[13] Woch F., Hernik J., Linke H.J., Sankowski E., Beczkowska M., Noszczyk T. Renewable Energy and Rural Autonomy: A Case Study with Generalizations. Polish Journal of Environmental Studies, Vol. 26, No. 6, 2017, pp. 2823-2832.

[14]Forys I., Gaca R. Theoretical and practical aspects of qualitative variable descriptions of residential property valuation multiple regression models. 10th Professor Aleksander Zelias International Conference on Modelling and Forecasting of Socio-Economic Phenomena, May 1013, 2016, Zakopane, Poland, pp. 36-44.

[15] Ministry of Economic Development. Strategy for Responsible Development for the period up to 2020 (including the perspective up to 2030), Warsaw 2017, 416 p.

[16] Boerenfijn P., Kazak J.K., Schellen L., van Hoof J. A multi-case study of innovations in energy performance of social housing for older adults in the Netherlands. Energy and Buildings, Vol. 158, 2017, pp. 1762-1769.

[17] Kazak J., van Hoof J., Szewranski S. Challenges in the wind turbines location process in Central Europe - The use of spatial decision support systems. Renewable and Sustainable Energy Reviews, Vol. 76, 2017, pp. 425-433.

[18] Pluciennik M., Heldak M., Szczepanski J., Patrzalek C. Application of Spatial Models in Making Location Decisions of Wind Power Plant in Poland. IOP Conference Series: Materials Science and Engineering, vol. 245, "World Multidisciplinary Civil Engineering-Architecture-Urban Planning Symposium - WMCAUS”, June 12-16, 2017, Prague, Czech Republic, 072016.

[19] Wang T., Han Q., de Vries B. A semi-automatic neighborhood rule discovery approach. Applied Geography, Vol. 88, 2017, pp. 73-83.

[20] GUS. Wskazniki zrownowazonego rozwoju Polski (Indicators of the sustainable development of Poland). Katowice: 2011. (In Polish), 195 p.

[21] Wskazniki zrownowazonego rozwoju (Indicators of the sustainable development) (In Polish), [online] [24.11.2017]. Available at: http://wskaznikizrp.stat.gov.pl/

[22] European Union. Regions in the European Union Nomenclature of territorial units for statistics NUTS 2013/EU-28. 2015. 
[23] Nipers A., Pilvere I., Zeverte-Rivza S., Krievina A. Use of econometric model for developing an outlook for livestock sector in Latvia. Proceedings of 16th International Scientific Conference "Engineering for rural development", May 24-26, 2017, Jelgava, Latvia, pp. 874-883.

[24] Dell Inc. Dell Statistica (data analysis software system), version 13, 2016.

[25] Spearman C. The proof and measurement of association between two things. American Journal of Psychology, vol. 15, no. 1, 1904, pp. 72-101.

[26] Forys I., Putek-Szelag E. Methods of linear ordering in estimation of potential of Polish market of agricultural property. Actual Problems of Economics, Vol. 151, Is. 1, 2014, pp. 542-550.

[27] Nagy H., Illes B., Kaposzta J., Donnik I. Clusters and concentration of businesses in regions of some European countries as tools for economic development. Proceedings of 16th International Scientific Conference "Engineering for rural development", May 24-26, 2017, Jelgava, Latvia, pp. 248-253.

[28] Tanas J., Trojanek R. Demographic structural changes in Poznan downtown: in the light of the processes taking place in the contemporary cities in the years 2008 and 2013. Journal of International Studies, Vol. 7, No 3, 2015, pp. 127-139. 